\title{
Correlation between Concepts of Legal Position and Decision of Body of the Constitutional Justice
}

\author{
Oleg A. Sidorov ${ }^{1}$, Marina A. Mokoseeva ${ }^{1} \&$ Tatiana N. Mikheeva ${ }^{1}$ \\ ${ }^{1}$ Mari State University, Yoshkar-Ola, Russia \\ Correspondence: Marina A. Mokoseeva, Mari State University, Lenin Square 1, Yoshkar-Ola city, Mari El \\ Republic, 424001, Russia. E-mail: mrn.mksv@gmail.com
}

$\begin{array}{lcc}\text { Received: February 21, } 2015 & \text { Accepted: March 15, } 2015 \quad \text { Online Published: April 29, } 2015 \\ \text { doi:10.5539/res.v7n8p221 } & \text { URL: http://dx.doi.org/10.5539/res.v7n8p221 }\end{array}$

\begin{abstract}
In the scientific article the author argues on similarities and distinctions between a legal position and the decision of the body of constitutional justice. The author reveals the issue of legal positions of bodies of the constitutional control as a complicated legal phenomenon and their influence on legal system of the Russian Federation.

The concept of a legal position of the Constitutional Court of the Russian Federation, signs and essence of this phenomenon are defined in the article. The features of formation of legal positions of the Constitutional Court of the Russian Federation are also studied here.

The author brings up the issues connected with the scope of research and tries to solve them in the conclusion of this article. For example, the author concerns a problem of lack of definitely issued mechanism of execution and application of legal positions in law-making and law-enforcement activity.
\end{abstract}

Keywords: Legal position, court decisions, the Constitutional Court, constitutional justice, constitutional law, the Russian legal system, a source of law

\section{Introduction}

The question of a correlation between the legal position and the decision of the constitutional control in the Russian theory and practice of the constitutional justice is under the discussion.

Relevance of the chosen subject is caused by position which is held by the constitutional justice in modern society. The constitutional court of the Russian Federation as a judicial authority of the constitutional control passes the decisions which have direct impact on the system of legislation of the Russian Federation, but legal positions, which are found in these decisions aren't investigated to the full extent. The absence of definition for legal position in the Russian legislation causes different approaches to its understanding and application.

Without exact idea of the juridical nature of legal positions and their correlation with decisions of the Constitutional Court their correct understanding and practical application is impossible. The reason is that special juridical nature of legal positions determines the mechanism of their impact on legislation and practice, the order of application and enforcement of responsibility for their non-performance or improper performance. (Shannon, 2007). Thus the question of correlation between the legal position and the decision remains open.

N. A. Vlasenko, G. A. Gadzhiyev, V. V. Yershov, K. N. Koroteyev, V. A. Kryazhkov, O. N. Kryazhkova, L. V. Lazarev, S. P. Mavrin, M. S. Salikov, and B. S. Ebzeev's works are devoted to the problems of definition and the juridical nature, questions of formation of legal positions of the Constitutional Court of the Russian Federation.

Some aspects of legal positions of the Constitutional Court of the Russian Federation were considered in V. I. Anishina, N. V. Vitruk, G. A. Gadzhiyev, O. V. Rmanova, V. G. Stepankov, and B. A. Strashun's works which analyze legal positions of the Constitutional Court of the Russian Federation as one of the sources of modern constitutional right.

The analysis of execution practice of decisions and the mechanism of realization of the legal positions of the Constitutional Court of the Russian Federation, which these decisions contain, was carried out on the basis of studying the works of I. A. Aleshkova, A. V. Bezrukov, N. S. Bondar, T. G. Borodinova, G. A. Gadzhiyev, V. D. Zorkin, A. V. Mazurov, A. A. Markin, N. V. Nikiforovskaya, S. S. Popov, G. V. Svintsov, and A. R. Sultanov.

However, despite of a significant amount of works on a research subject in legal literature, there is no consensus 
concerning the concept of the juridical nature of legal positions of the Constitutional Court of the Russian Federation and their correlation with decisions of the Constitutional Court. It means there are no researches to form a complete picture of this legal phenomenon (Pirbudagova, 2003).

In this regard the subject of the real research is important and has not only theoretical, but also practical value. So, relevance of the chosen subject is caused by a special role of final decisions and the legal positions, included into these decisions, in the Russian legal system.

The analysis, carried out in this scientific article, showed the necessity for qualification of a legal position as many scientists and experts, for example, A. V. Grineva, identify a legal position with the judgment and the comment of the judgment in the press. It happens due to understanding the legal position (in a broad sense this word) as "... estimation of legal reality, system of the legal arguments which are the cornerstone of the legislation, judicial and other law-enforcement activity. It is the logic-language construction, expressing the subject's relation to the legal phenomena and processes". Consequently, there is a mixture of the legal doctrine, ways (forms) of law application and the forms of rules of law interpretation.

Thus, research showed that there are problems in realization of legal positions especially by the public authorities owing to lack of accurately issued mechanism of execution and application of legal positions in law-making and law-enforcement activity (Bevzenko, 2013).

The objective of the following research is to determine the distinctions between the legal position and the decision of the constitutional justice, to identify the essence of legal positions of bodies of the constitutional control as a complicated legal phenomenon and their influence on legal system of the Russian Federation.

In order to achieve the objective of the research the following tasks were set: to define the content of a legal position of the Constitutional Court of the Russian Federation", the essence of this phenomenon; to study features of formation of legal positions of the Constitutional Court of the Russian Federation; to reveal a correlation between concepts of the legal position of the Constitutional Court of the Russian Federation and the decision of the Constitutional Court of the Russian Federation.

\section{Methods}

Methodological basis of the research consists of the set of scientific knowledge methods. In the course of writing this scientific work different methods were applied. The author uses general scientific methods: the scientific analysis (the analysis of theoretical sources), a synthesis method, system and structural, a method of generalization of the received materials on the studied subject, structurally functional, historical, as well as private scientific methods: technical and legal, comparative, formal-legal. Their use allowed to reveal the main problems connected with legal positions and to offer recommendations about their elimination.

\section{Results}

Decisions of the Constitutional Court should be distinguished from its legal positions. Their emergence is caused by the role which is carried out by bodies of the constitutional control in modern society at this stage of development, and also by validity of their decisions. Various points of view on this legal phenomenon and its influence on development of the Russian legal system are expressed (Mikheyeva \& Mikheyev, 2014).

The concept "legal position" has gained the greatest distribution in legal literature in relation to activity of the Constitutional Court of the Russian Federation. The Constitutional Court, being a judicial body of constitutional review, has a public authority to take decisions that have binding effect. Thus it is not only about negative law-making, but also about such cases, when Court acts as a positive legislator, formulating the legal positions of standard character having the validity close to the constitution (Marshall, Brett, \& Pacelle, 2014; Ergubaev, 2001).

The decision of the Constitutional Court is a legal act in which the Constitutional Court expresses its will within the competence. The decision is a fundamental element in the constitutional legal proceedings as the decision proclaimed by the Constitutional Court finishes process of consideration of the case. According to Art. 71 of FCL "About the Constitutional Court of the Russian Federation" the Court assumes the following decisions: ruling, determination and conclusions.

The legal position is a system of the legal arguments and conclusions which are the cornerstone of the decision of the Constitutional Court. Legal positions form a legal ground of final decisions, they solve constitutional and legal uncertainty.

For the first time the legislative concept "al position" was published in the Federal constitutional law of July 21, 1994 N 1-FCL "About the Constitutional Court of the Russian Federation". Art. 73 of this Law contained 
regulations, according to which " ... in case most of the judges participating in a meeting of chamber incline to need to make the decision which isn't corresponding to the legal position expressed in earlier made decisions of the Constitutional Court of the Russian Federation, case is submitted to plenary session". However, this article was excluded from the text of the law in 2010. But the phenomenon remained and began to develop.

Even more often this term began to be used also concerning judgments of courts of all instances, including the Constitutional or Supreme Courts of the Russian Federation, and also as the concept defining the set of a state governing body. It is possible to give the letter of Federal Tax Service of Russia of January 31, 2014 of N CA-4-14/1645 as an example of it. Thus, legal positions even more often lay down at the basis of the argument, justification of a total legal judgment (Hajiyev, 2012).

Let us address to some examples of the legal positions included into definitions of the Constitutional Court of the Russian Federation to which one refers in order to justify the adopted judgment.

1) The legal positions on the content of the federalism principles fixed in the decision CC Russian Federation of June 7, 2000: the sovereignty of Russia doesn't allow existence of two levels of the sovereign authorities, that is doesn't allow the sovereignty the republics, other territorial subjects of the Russian Federation;- - subjects of Federation don't possess the sovereignty; - the use of the concept "republic (state) in the Constitution of the Russian Federation “ doesn't mean recognition of the state sovereignty of these territorial subjects of the Russian Federation, and only reflects certain features of their constitutional legal status in terms of historical, national, geographical features, etc.; - the constitution of the Russian Federation is the act which establishes the status of the territorial subject of the Russian Federation, neither the agreement of the Russian Federation and its subject, nor the federal constitutional law on the validity the Constitution of the Russian Federation can't be higher.

2) According to the legal position contained in decision of the Constitutional Court of the Russian Federation of June 27, 2000 No. 92-O: the republic can't be subject of the international relations, can't sign international legal contracts.

However in compliance with Art. 72 of the item "o" p. 1 and the Art. of 76 p. 2 Constitutions of the Russian Federation the republic can carry out the international and foreign economic relations provided that they don't affect (points "k", "l", "m", "n") power and a prerogative of the Russian Federation provided by its article 71 as sovereign state and that coordination of such communications is defined by the federal law, other laws and regulations of territorial subjects of the Russian Federation adopted on its basis. Proceeding from it, by the Federal law of January 4, 1999 "About coordination of the international and foreign economic relations of subjects of the Russian Federation" it is established that subjects of Russia have rights for implementation of the international and foreign economic relations with subjects of foreign federal states, administrative-territorial formations of the foreign states, and also on participation in activities of the international organizations within the bodies, created especially for this purpose.

3) The decision of the Constitutional Court of the Russian Federation of December 27, 1999 contains legal positions on mechanisms of realization and protection of constitutional rights and freedoms of citizens: establishment of age limit at replacement of certain positions, according to the employment contract, is admissible if this restriction is caused by specification and features of the performed work; - at introduction of such age restrictions observance of the constitutional principle of the equality excluding unreasonable presentation of different requirements to the persons, who carry out functions, identical on the content, has to be provided; - otherwise establishing the age limit, which accomplishment becomes the reason for dismissal, regardless of the employee's consent, is considered as age discrimination.

4) Legal positions of the Constitutional Court on legislative procedures and action of legal acts, contained in decision of the Constitutional Court of November 5, 1999 No. 182-O, establish that article 76 of the Constitution of the Russian Federation doesn't define the hierarchy of acts inside one type, in this case-federal laws. No federal law possesses greater legal power in relation to another federal law by virtue of Article 76 of the Constitution of the Russian Federation.

The analysis of legal positions of the Constitutional Court of the Russian Federation given above showed one more their feature: not only legal positions influence the decision made by the Constitutional Court, but also the decision influences legal positions. The statement of legal positions of the Constitutional Court in its decisions makes them official.

\section{Discussions}

The subject of research in is very debatable, especially it concerns definition of concept and essence of a legal position. The concept of the decision of the Constitutional Court is rather well settled in the theoretical and 
practical plan, while there are certain doubts concerning the essence of a legal position concept. Decisions of the Constitutional Court are the legal act consisting of introduction, motivation and resolutoly part. It is the formulation of the decision stated in resolutoly part. On the basis of legal positions the Constitutional Court makes decisions, draws final conclusions concerning interpretation of the constitution, abstract or concrete compliance assessment, etc.

At implementation of the activity the Constitutional Court of the Russian Federation will be able to formulate a legal position as in motivation, and resolutory parts of its rulings and determinations

According to G. A. Gadzhiyev, the judge of the Constitutional Court of the Russian Federation, legal positions of the Constitutional Court are "the important legal conclusions, ideas representing the crystallized right revealed by court, the right source, a legal principle suitable for permission of group of similar legal collisions" (Gadzhiyev, 1999, 2013).

V. A. Kryazhkov considers that the legal position of the Constitutional Court of the Russian Federation is "logical and legal justification of a final conclusion of the Court contained in the deciding part of its decision, formulated in the form of the legal conclusions, which have obligatory value" (Kryazhkov, 2005).

According to B. S. Ebzeev, "legal positions ... are the conclusions of court which result from interpretation of the Constitution of the Russian Federation by Court, its spirit and letter, legal principles, revealed by it, and the cornerstone decisions" (Ebzeev, 2007, p. 84).

In our opinion, it is necessary to unify semantic contents of this term, and to define its broad and narrow sense. It is obvious that the current practice of its use unnecessarily expands the boundaries of legal significance, which includes the term at the time of adoption of the Law on the Constitutional Court of the Russian Federation (Mokoseeva, 2014; Kokotov, 2013).

Thus, the frequency of the usage of this phrase in legal practice increases. Accordingly, the meaning of "legal position" is not so much expanded and concretized as it is lost. Everyone puts his own understanding and meaning into it.

Absence of the formulation of a legal position in the law causes different approaches to its understanding. Summarizing each of the provided statements, we believe that legal positions of the Constitutional Court of the Russian Federation are conclusions on a certain problem to which the court arrived at solving some concrete case, having repeated character, and also possessing validity, as well as decisions of the Constitutional Court (Panteleev, 2012).

Thus, such jurists as G. A. Gadzhiyev, L. V. Lazarev, and V. A. Kryazhkov specify a legal standardization as the most important sign of a legal position of the Constitutional Court and consider legal positions of Court as a law source, but not the decisions. B. A. Starshun, I. V. and Sukhinina don't agree with these the statement. They consider that "judgments ... should be considered as a law source".

In spite of the fact that this article is focused on the Russian legal system, it would be interesting to give an example from foreign practice. In Norway the part of the final act of the Supreme Court has to contain "legal view of judges" (rettsoppfatning) on the basis of which they take final decision. Also, there is the regulation, according to which judgment should express the sense of justice (uttalt rettsoppfatning). Norms of this kind allow us to draw a conclusion on existence of legal positions of court in foreign legal acts - the sense of justice, outlook of judges which are a basis for acceptance of a total conclusion of court.

\section{Conclusion}

Summarizing each of the statements given above, we come to the following conclusions:

1) Concepts of legal position and decision of the Constitutional Court of the Russian Federation are not identical. Legal positions have repeated character, and decisions of the Constitutional Court are made on concrete cases.

2) We believe that legal positions of the Constitutional Court are the reasoned conclusions on a certain problem to which the court comes solving concrete cases, having repeated character, that is the adoption of the final decision applied by consideration of the same problems, the cornerstone and also possessing validity, as well as decisions of the Constitutional Court of the Russian Federation.

We note that it is necessary to fix the concept "legal position of the Constitutional Court of the Russian Federation", "legal position of the Supreme Court of the Russian Federation" in legal definitions at the legislative level in order to eliminate revealed discrepancies and gaps of substantial character.

In the theory of the right it is required to develop uniform understanding of legal value of this phenomenon or as 
right source, or as special, obligatory form of judicial interpretation.

3) Legal positions of the Constitutional Court, as well as the decision, are obligatory. They have identical validity and are obligatory on the whole territory of the Russian Federation.

4) Legal positions, unlike decisions of the Constitutional Court of the Russian Federation, don't finish process of consideration of concrete case, but they are the cornerstone of the decision made by the Constitutional Court and its argumentation.

So, an opinion of most of judges during adoption of the final decision becomes a legal position of the Constitutional court.

During disposition of concrete cases judges develop the legal positions containing professional and authoritative outlook, meeting lacks in the right and resolving contradictions in the current legislation.

The judge has to solve the incidents in legal reality that isn't regulated by the legislator. Due to the gap in the right the judge doesn't have a necessary law at hand. However, he is obliged to solve dispute on the basis of the general principles of the right. The legal positions of the Constitutional Court of the Russian Federation, brought out of the precepts of law which are available in legal base of our country, help him.

5) The distribution of action of the accepted legal position on similar affairs is one of the important signs, inherent in legal positions of the Constitutional Court of the Russian Federation.

This sign shows, in particular, that the decision of the Constitutional Court of the Russian Federation about inconsistency of the normative legal act to the constitution extends not only on this act, but also on acts founded on its basis, either reproducing it or containing the same regulations which were a subject of the judicial recourse.

6) The statement of legal positions in decisions of the Constitutional Court makes them official.

7) Legal positions of the Constitutional Court of the Russian Federation, unlike its decisions, can be reconsidered. The final judgment can't be reconsidered.

Still the final decision (conclusion) and a position are connected indissolubly with each other, because the legal position can be contained both in motivational, and in resolutive parts of the decision.

The legal act is admitted unconstitutional only by the final decision, contained in resolutive part.

8) Legal positions of the Constitutional Court of the Russian Federation are obligatory for execution irrespective of a type of decisions of the Constitutional Court of the Russian Federation in which they are contained.

Also here is a problem connected with application of legal positions of the Constitutional Court of the Russian Federation in jurisprudence stated in so-called earlier non-final decisions made, generally, in the form of definitions. In fact, till November 3, 2010 when new edition of the Federal constitutional law "About the Constitutional Court of the Russian Federation" came into force, the Constitutional Court of the Russian Federation accepted numerous definitions containing the revealed constitutional and legal sense of the precepts of law considered by court. These include definitions about explanation of the decisions which were accepted earlier by the Constitutional Court of the Russian Federation.

It appears that this problem needs to be settled by updated modification of h. The 5th Art. 79 of FKZ "About the Constitutional Court of the Russian Federation", declaring that legal positions of the Constitutional Court of the Russian Federation are obligatory for execution within the territory of the Russian Federation all legal entities, including judicial instances of all levels.

This approach will promote ensuring legal definiteness of legal regulation which, in our opinion, will have positive influence on the whole Russian legal system.

\section{References}

Bevzenko, R. S. (2013). Legal positions of the Supreme Arbitration Court of the Russian Federation on the guarantee and bank guarantee. In the comment to Resolutions of Plenum of the Supreme Arbitration Court of the Russian Federation of July 12, $2012 \mathrm{~N} 42$ "About some questions of settlement of disputes connected with the guarantee" and of March 23, 2012 N 14 "About the single questions of practice of settlement of disputes connected with contest of bank guarantees". Moscow.

Bryan, W. M., Brett W. C., \& Richard L. P. (2014). Preserving Institutional Power: The Supreme Court and Strategic Decision Making in the Separation of Powers. Politics \& Policy. http://dx.doi.org/10.1111/polp.1206 
Ergubaev, Z. (2001). About some shortcomings of legal regulation of constitutional (statutory) courts of subjects. Problems of implementation of the federal authorities of state power and state authorities of the Russian Federation, decisions of the Constitutional Court of the Russian Federation and the constitutional (statutory) courts of the subjects of the Russian Federation. In M. A. Mityukova, S. V. Kabysheva, V. K. Bobrova, S. E. Andreev (Eds.), Proceedings of the All-Russia meeting. Moscow.

Gábor, H. (2012). Unconstitutional Constitutional Amendments: Constitutional Courts as Guardians of the Constitution? Constellations. http://dx.doi.org/10.1111/j.1467-8675.2012.00688.x

Ebzeev, B. S. (2007). The constitutional court of the Russian Federation-Judicial authority of the constitutional control. Messenger of the Constitutional Court, 2, 84.

Gadzhiyev, G. A. (2013). Methodological problems of "case revolution" in Russia. The Magazine of the constitutional justice, 7-8.

Gadzhiyev, G. A. (1999). Legal positions of the Constitutional Court of the Russian Federation as source of a constitutional law. Constitutional right: East European review, 82.

Hajiyev, G. (2012). Comments to the Federal Constitutional Law "About the Constitutional Court of the Russian Federation". Moscow.

Kokotov, A. (2013). Execution of the decisions of the Constitutional Court of the Russian Federation. Journal of Russian law, 90-101.

Kryazhkov, V. A. (2005). Legal positions of the Constitutional Court of the Russian Federation in its interpretations. States and the right, 13-21.

Mokoseeva, M. A. (2014). Reasons of non-execution of decisions of regional bodies of the constitutional control. Business in the law, 115-118.

Mikheyeva, T. N., \& Mikheyev, D. S. (2014). A legal vector in development of public control. The Legal world, 16-19.

Mikheev, D. S. (2014). Legal analysis of the European charter of the local self-government in the light of the principle of publicity. Life Science Journal, 620.

Panteleev, V. (2012). Topical issues of modernization and increase the efficiency of constitutional justice in the Russian Federation. Constitutional and municipal law, 3, 46-51.

Pirbudagova, D. (2003). Institute of constitutional control and protection of the constitutional legality in the Republic of Dagestan: The history, theory and practice. Makhachkala.

Shannon, R. (2007). Permutations of Judicial Power: The New Constitutionalism and the Expansion of Judicial Authority. Law \& Social Inquiry. http://dx.doi.org/10.1111/j.1747-4469.2007.00068.x

\section{Copyrights}

Copyright for this article is retained by the author(s), with first publication rights granted to the journal.

This is an open-access article distributed under the terms and conditions of the Creative Commons Attribution license (http://creativecommons.org/licenses/by/3.0/). 